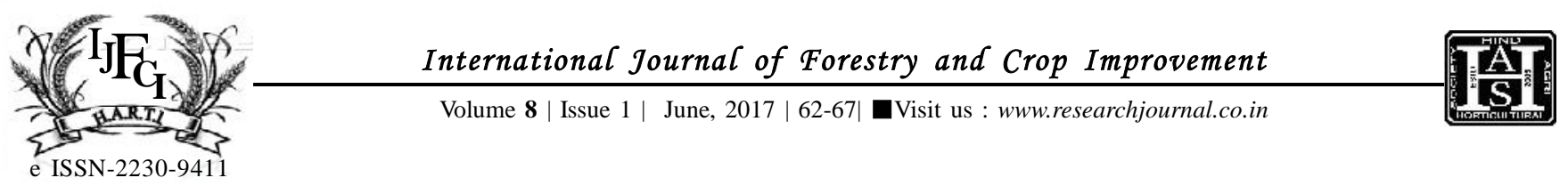

RESEARCH ARTICLE

DOI: $10.15740 / \mathrm{HAS} / \mathrm{IJFCI} / 8.1 / 62-67$

\title{
Weed management practices in Zaid urdbean under different sowing dates
}

\author{
HARPHOOL MEENA AND B.L. KUMHAR
}

\begin{abstract}
An experiment was conducted during two consecutive years of Zaid 2008 and 2009 at Agricultural Research Station, Borwat Farm, Banswara to find out optimum sowing date and suitable herbicide for weed management in Zaid urdbean under Humid Southern Plain Zone of Rajasthan. Results revealed that the maximum seed yield (961 kg/ha), net return (Rs. 23848/ - ha ${ }^{-1}$ ) and B: C (1.45) was observed under sowing of urdbean on $15^{\text {th }}$ March over sowing of urdbean on $5^{\text {th }}$ and $15^{\text {th }}$ April, respectively. However, it was found at par withsowing of urdbean on $25^{\text {th }}$ March seed yield $(924 \mathrm{~kg} / \mathrm{ha}$ ), net return (Rs. 22769/- ha$\left.{ }^{1}\right)$ and B: C (1.42). In weed management, application of Fluchloralin @ $0.75 \mathrm{~kg}$ a.i./ha PPI gave significantly higher seed yield (918 $\mathrm{kg} / \mathrm{ha}$ ) net return (Rs. 21888/- ha ${ }^{-1}$ ) and B:C (1.33) over weedy check (control), but it was found at par with application of Pendimethalin@0.75 kg a.i./ha PE and weed free in the pooled analysis. Sowing of urdbean under different dates, the weed population $\mathrm{m}^{-2}$, weed dry matter accumulation $\left(\mathrm{g} \mathrm{m}^{-2}\right)$ and weed control efficiency at $30 \mathrm{DAS}$ were found not significant with each other during both the years as well as in the pooled analysis. Application of Fluchloralin @ $0.75 \mathrm{~kg}$ a.i. /ha PPI gave significantly higher weed control efficiency $(51.80 \%)$, lowest weed population $\left(13.40 \mathrm{~m}^{-2}\right)$ and weed dry matter accumulation $\left(15.57 \mathrm{~g} \mathrm{~m}^{-2}\right)$ at 30 DAS over weedy check (control), but it was found at par with the application of Pendimethalin @ $0.75 \mathrm{~kg}$ a.i./ha PE and weed free in the pooled analysis.
\end{abstract}

KEY WORDS : Urdbean, Zaid, Weed management, Sowing date

HOW TO CITE THIS ARTICLE : Meena, Harphool and Kumhar, B.L. (2017). Weed management practices in Zaid urdbean under different sowing dates. Internat. J. Forestry \& Crop Improv., 8 (1) : 62-67, DOI: 10.15740/HAS/IJFCI/8.1/62-67.

ArTiCle Chronical : Received : 01.04.2017; Revised : 09.05.2017; Accepted : 23.05.2017 